\title{
A new species of the genus Trouessartia Canestrini (Acari: Trouessartiidae) from Neotropical passerines (Aves: Tyrannidae)
}

\section{Fabio Akashi Hernandes \& Michel P. Valim}

To cite this article: Fabio Akashi Hernandes \& Michel P. Valim (2015) A new species of the genus Trouessartia Canestrini (Acari: Trouessartiidae) from Neotropical passerines (Aves: Tyrannidae), International Journal of Acarology, 41:5, 382-388, DOI: 10.1080/01647954.2015.1046921

To link to this article: https://doi.org/10.1080/01647954.2015.1046921

曲 Published online: 12 May 2015.

Submit your article to this journal $\widetilde{ }$

Џ Article views: 50

View Crossmark data \ulcorner

Citing articles: 6 View citing articles ๘ 


\title{
A new species of the genus Trouessartia Canestrini (Acari: Trouessartiidae) from Neotropical passerines (Aves: Tyrannidae)
}

\author{
Fabio Akashi Hernandes ${ }^{\mathrm{a}}$ and Michel P. Valim ${ }^{\mathrm{b}}$ \\ ${ }^{a}$ Departamento de Zoologia, Universidade Estadual Paulista, Rio Claro, Brazil (email: abakashi@gmail.com); ${ }^{b}$ Serviço de \\ Invertebrados-Entomologia, Museu de Zoologia da Universidade de São Paulo, Ipiranga, Brazil (email: mpvalim@hotmail.com)
}

(Received 24 February 2015; accepted 27 April 2015; published online 12 May 2015)

\begin{abstract}
A new species of the feather mite genus Trouessartia Canestrini (Acari: Trouessartiidae) is described from Myiobius atricaudus Lawrence, 1863 (Aves: Passeriformes: Tyrannidae) from Brazil. Trouessartia longiducta sp. nov. is remarkable in having the longest external copulatory tube in females among species of the genus Trouessartia. It differs from the closest species T. geospiza OConnor et al., 2005 in having the female copulatory tube extending beyond the level of lobar apices.

http://zoobank.org/urn:lsid:zoobank.org:pub:E46D73C3-0C6E-4A96-8F60-DCF84A3ED500
\end{abstract}

Keywords: Astigmata; feather mite; systematics; taxonomy; Brazil; wing mite

\section{Introduction}

The Astigmata exhibits some of the most impressive examples of sexual dimorphism of acariform mites, especially within the Psoroptidia. This is especially remarkable considering that astigmatids most likely evolved from an asexual lineage of oribatids, the Desmonomata (Norton 1998; Dabert et al. 2010; Walter and Proctor 2013). Noteworthy examples of sexually dimorphic traits include males with asymmetrical hypertrophy of legs such as Dinalloptes Gaud and Mouchet, 1957 and Hyperpedalloptes Dubinin, 1955 (Alloptidae) (Gaud and Atyeo 1996); males with extremely elongated aedeagi such as Anisodiscus goodmani Hernandes and OConnor, 2013 (Proctophyllodidae), in which the aedeagus is nearly two times the length of the idiosoma (Hernandes and OConnor 2013); females with the primary duct of the spermatheca hyper-elongated such as Amerodectes thraupicola (Černý, 1974) (about $600 \mu \mathrm{m}$, which is longer than the idiosoma of females, and nearly four times the length of the same structure in other Amerodectes species) (Valim and Hernandes 2010); or females with external copulatory tubes that appear designed to penetrate the distal part of the male genital apparatus, such as feather mites of the families Crypturoptidae (Gaud et al. 1972), Eustathiidae (Peterson et al. 1980), and most species of the genus Trouessartia Canestrini (Trouessartiidae) (Santana 1976).

In the latter family, females of many species of Trouessartia may have an external copulatory tube (containing the distal part of the primary spermaduct) at the anterior margin of the terminal cleft that varies in length and shape, from cylindrical and apically truncate as in T. latiducta Hernandes, 2014 to long and thin as in T. geospiza OConnor et al., 2005; in some species, the external tube is completely absent, like in $T$. longifolia Gaud and Mouchet, 1958 and T. picumni Hernandes, 2014. In this paper we describe a new Trouessartia species with the longest (in absolute length) known female copulatory tube.

\section{Materials and methods}

Mites were collected from live birds captured with mist-nets by Enout et al. (2012) in the Brazilian state of Tocantins in 2008 and 2009. All mite specimens were mounted on glass slides in Hoyer's medium (Krantz and Walter 2009). The descriptive method, morphological terminology, setal nomenclature and measurement technique follow recent papers on the taxonomy of the genus Trouessartia (OConnor et al. 2005; Carleton and Proctor 2010; Constantinescu et al. 2013; Mironov and González-Acuña 2013; Hernandes 2014). Bird nomenclature and classification follow Dickinson (2003). Type specimens are deposited at DZUnesp-RC - Acari Collection of the Department of Zoology of the Universidade Estadual Paulista, campus of Rio Claro, São Paulo State, Brazil.

\section{Analgoidea Trouessart and Mégnin, 1884 Trouessartiidae Gaud, 1957 Trouessartia Canestrini, 1899}

Type species: Dermaleichus corvinus Koch, 1841, subsequent designation by Oudemans (1897, p. 266).

The genus Trouessartia is the species-richest genus within the family Trouessartiidae, and one of the most diverse feather mite genera, including nearly 110 named species (Mauri and De Alzuet 1968; Černý and Lukoschus 1975; Santana 1976; Gaud 1977; Černý 1979; Mironov 1983; Gaud and Atyeo 1986, 1987; Mironov and Kopij 1996, 2000; Mironov and Galloway 2002; OConnor et al. 2005; Carleton and Proctor 2010; Constantinescu et al. 2013; Mironov and González-Acuña 2013; Hernandes 2014). They are most commonly found on the dorsal surface of large wing feathers (mainly the large primaries, secondaries and tertiaries) and tail feathers (rectrices) (Dabert and 
Mironov 1999; Mestre et al. 2011; Mironov and González-Acuña 2013). Santana (1976) estimated that the 71 species redescribed in his work would represent merely $10-15 \%$ of the real diversity, given the relative low proportion of passerine hosts that had been explored for Trouessartia species; this would mean this genus could actually comprise over 500 species. In Brazil, despite having more than 900 passerine species, only 13 nominal species of Trouessartia have been described or reported (Berla 1959a, 1959b, 1960, 1962; Kanegae et al. 2008; Valim et al. 2011; Hernandes 2014).

\section{Trouessartia longiducta sp. nov.}

(Figures 1-5)

Trouessartia sp. (ex Myiobius atricaudus), Enout et al., 2012, p. 1737

Type-host: Myiobius atricaudus Lawrence, 1863 (Passeriformes, Tyrannidae), the black-tailed flycatcher.

Type-locality: Trilha das Araras, Taquaruçu, Tocantins, Brazil.
Type material. Male holotype (\#2731), 7 males and 11 female paratypes ex M. atricaudus, band \#D85492, BRAZIL: Tocantins, Ecotropical Institute, Taquaruçu, trilha das araras, $10^{\circ} 16^{\prime} 52^{\prime \prime} \mathrm{S}, 48^{\circ} 09^{\prime} 35^{\prime \prime} \mathrm{W}, 5$ November 2008, coll. A.M.J. Enout.

Additional material. 10 males, 9 females and 2 nymphs, ex $M$. atricaudus, same data as for type material, except band \#C56498, 18 March 2009, coll. A.M.J. Enout. 1 female and 1 nymph, same data, except band \#D85489, 4 November 2008.

\section{Etymology}

The specific epithet refers to the long external copulatory tube on females; longi- (Latin; over a great extent, a long way, far) plus - ducta (Latin; to conduct, lead, take).

\section{Description}

Male (holotype, range for 4 paratypes in parentheses). Length of idiosoma from anterior end to bases of setae h3 552 (548-563), greatest width of idiosoma at level of

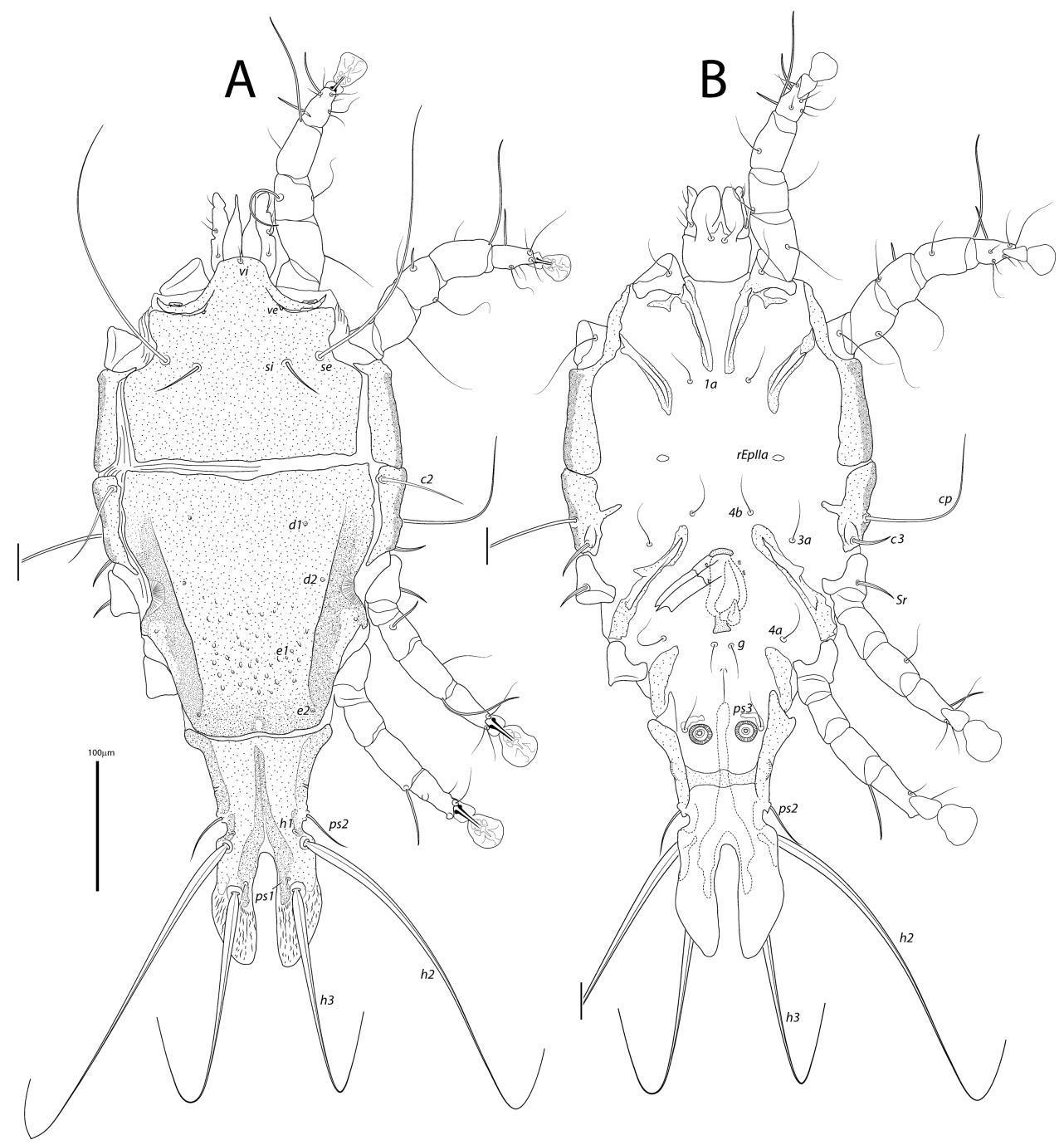

Figure 1. Trouessartia longiducta sp. nov., male. (A) dorsal view; (B) ventral view. 


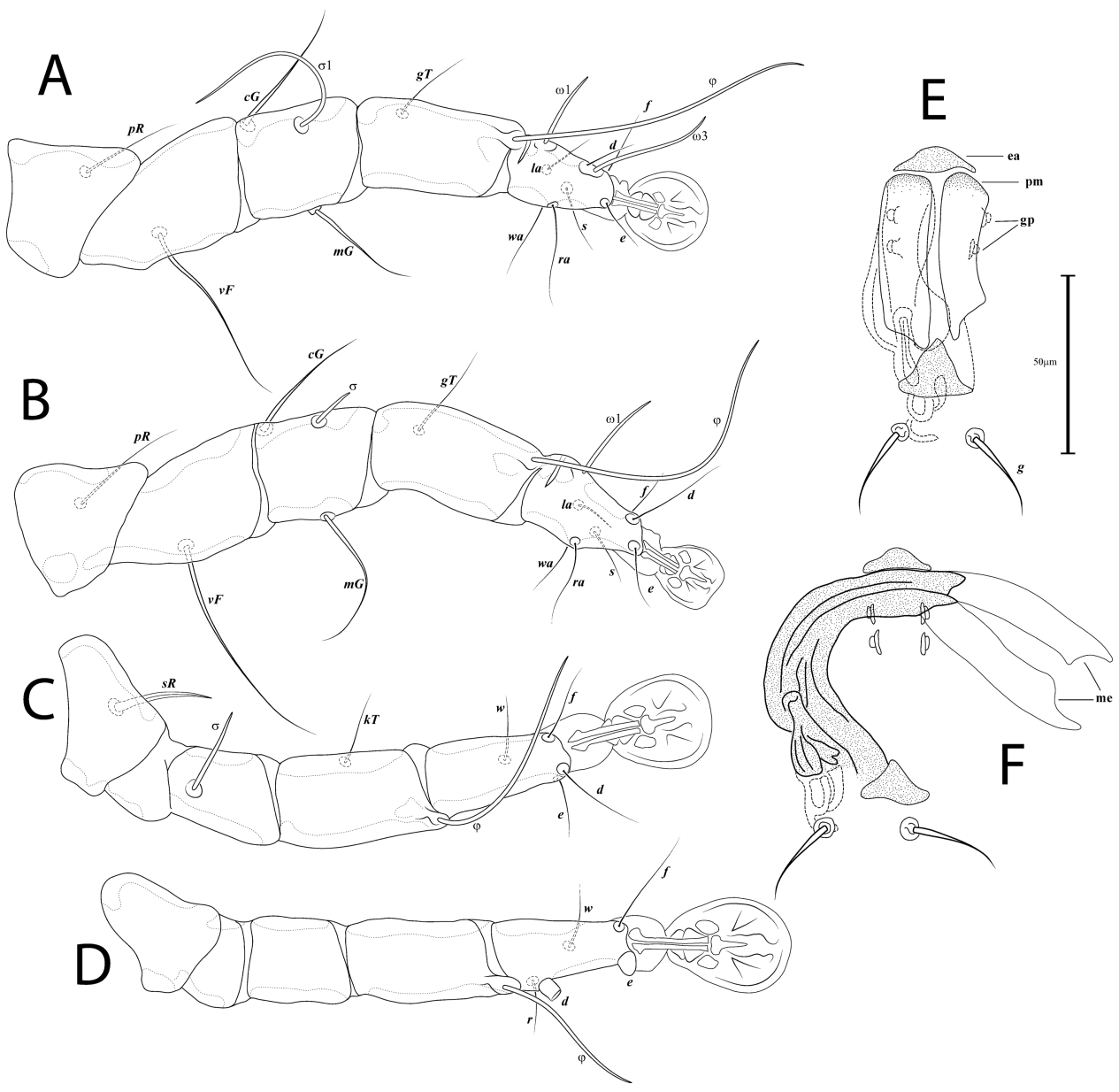

Figure 2. Trouessartia longiducta sp. nov., dorsal view of male legs I (A), II (B), III (C), and IV (D); ventral (E) and lateral (F) views of male genital apparatus (ea = epiandrum; $\mathrm{pm}=$ parameres; $\mathrm{gp}=$ genital papillae; $\mathrm{me}=$ membranous extensions of parameres).

humeral shields 232 (231-242). Length of hysterosoma from sejugal furrow to bases of setae $h 3331$ (332-343). Prodorsal shield: length along midline 155 (154-160), greatest width of posterior part 186 (184-186), lateral margins at level of trochanters II with shallow concavities, antero-lateral extensions almost extending to bases of epimerites Ia between legs I and II, lateral margins of posterior part not fused with scapular shields, posterior margin straight, surface smooth (Figure 1A), in some specimens with barely discernible network pattern. Vertical setae ve represented by alveoli. Internal scapular setae $s i$ thin needle-like, 31 (33-34) long, separated by 74 (70-77); external scapular setae se 182 (185-198) long, separated by 120 (119-122). Humeral shield with setae $c 2$ needle-like, 62 (63-68) long. Setae c3 narrowly lanceolate, acute apically, 31 (27-35) long. Prohysteronotal and lobar shields completely separated. Prohysteronotal shield: length 198 (200-205), width at anterior margin 188 (194), lateral margins with shallow incisions at level of trochanters III, dorsal hysterosomal apertures (DHA) absent, posterior area with small circular lacunae (Figure 5D). Dorsal setae $d 1, d 2$ present, minute. Setae $f 2$ indistinct. Length of lobar shield excluding lamellae 188 (117-137). Apical parts of opisthosomal lobes approximate, separated by narrow parallel-sided terminal cleft, length of cleft from anterior end to apices of lamellae 91 (88-96), width in anterior part 20 (15-20). Lamellae oblong in shape, slightly attenuate apically, margins smooth (Figure 5E), length from bases of setae $h 3$ to lamellar apices 62 (59-65). Setae h2 293 (212-284) long, setae h3 225 (225-240) long.

Epimerites I free. Rudimentary sclerites rEpIIa small, circular. Humeral shield ventrally fused with epimerites III and forming a finger-like extension (inner tip of epimerite) directed to meson. Genital apparatus situated between levels of trochanters III, IV, length 70 (6572), greatest width 37 (34-44) (Figure 1B). Small and flattened epiandrum present (Figure 2E, ea); anterior part of genital apparatus (parameres sensu Gaud and Atyeo 1986, Figure 2E, pm) with two membranous gutter-like extensions (Figure 2F, me). Postgenital plaque absent, setae $g$ thin, filiform (Figures 2E-F). Adanal apodemes heavily sclerotized, with small rounded 


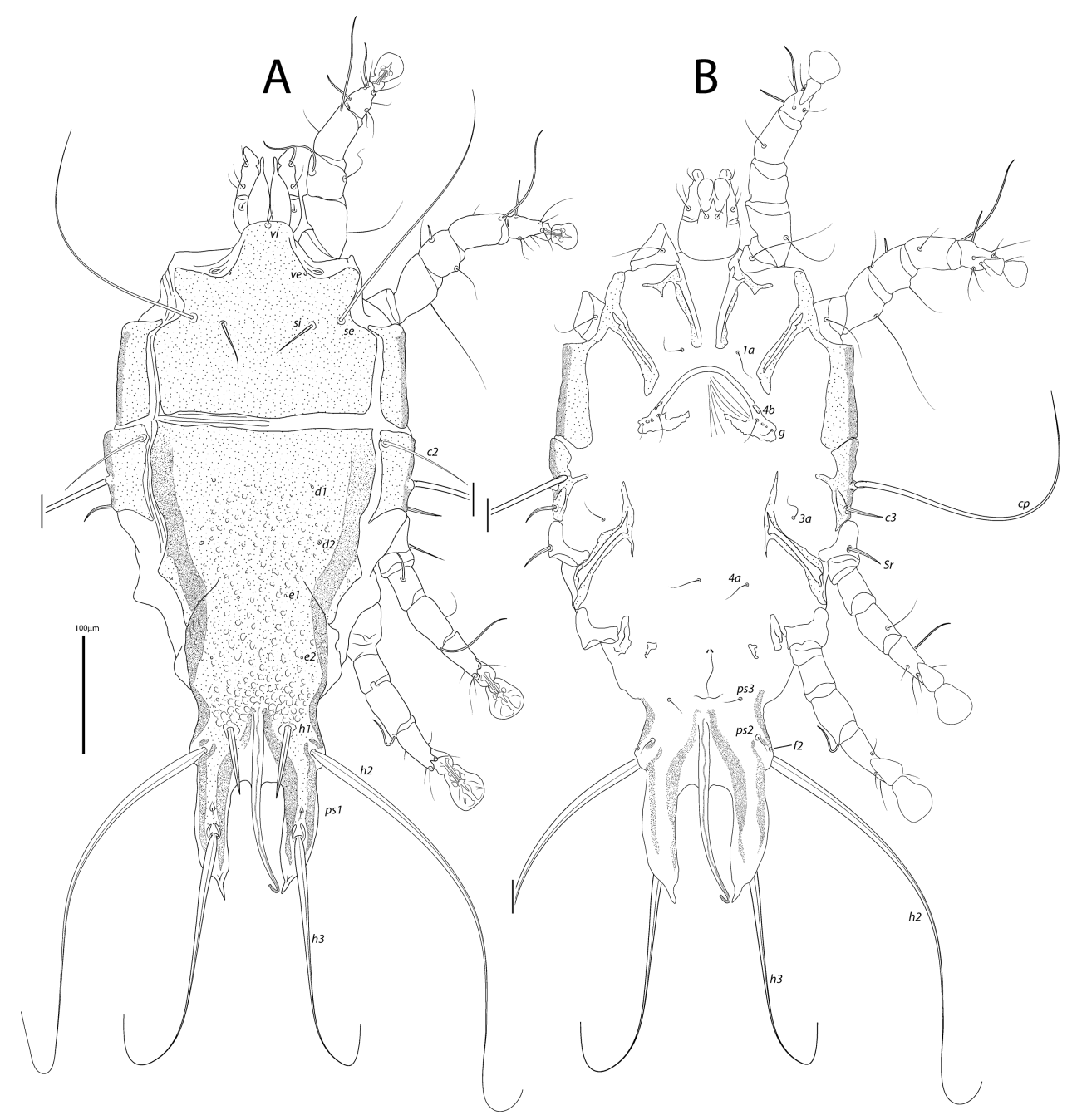

Figure 3. Trouessartia longiducta sp. nov., female. (A) dorsal view; (B) ventral view.

apophyses. Translobar apodeme present. Setae ps3 inserted on faint adanal shields of irregular form. Anal suckers 16 (16-18) in diameter, distance between centres of discs 34 (35-41). Epimerites IVa wide and long, anterior ends reaching level of setae $4 a$. Setae $4 b$ situated anterior to level of setae $3 a$, setae $g$ and $4 a$ situated approximately at same transverse level.

Legs IV extending by ambulacral disc to level of setae $h 2$. Setae $s R$ of trochanters III short, narrowly lanceolate, acute apically, 30 (28-32) long. Modified setae $d$ of tarsus IV barrel-shaped, with discoid cap, situated basally on segment; modified setae $e$ hemispheroid, without cap, situated apically (Figure 2D). Length of solenidia: $\sigma 1$ of genu I 46 (44-62), $\sigma$ of genu II $12(15-20), \sigma$ of genu III $29(16-29), \varphi$ of tibia I 84 (78-84), $\varphi$ of tibia II 89 (83$89), \varphi$ of tibia III $67(56-76), \varphi$ of tibia IV $41(41-47), \omega 1$ of tarsus I 24 (23-38), $\omega 3$ of tarsus I 39 (25-39), $\omega 1$ of tarsus II 30 (27-31).

Female (range for 5 paratypes). Length of idiosoma from anterior end to apices of lamellar lobar processes
568-575, greatest width 227-259. Length of hysterosoma from sejugal furrow to apices of lamellar lobar processes 352-356. Prodorsal shield: shaped as in male, 159-165 in length, 185-193 in width, surface as in the male (Figure 3A). Vertical setae ve represented by alveoli. Setae si thin needle-like, 32-38 long, separated by 72-75; setae se 169-191 long, separated by 121-125. Humeral shields with setae $c 2$ needle-like, 64-76 long. Setae c3 narrowly lanceolate, acute apically, 29-33 in length. Hysteronotal shield: length from anterior margin to bases of setae $h 3$ 347-353, width at largest part near anterior margin 185-193, lateral margins with incisions at level of trochanters III, DHA absent, surface with defined circular lacunae between levels of setae $d l$ and $h l$ (Figure 5A). Dorsal setae $d 1, d 2$ present. Setae $h 1$ dagger-like (Figure 5B), 55-58 long, situated antero-mesal to bases of setae $h 2$. Width of opisthosoma at level of setae h2 112-117. Setae ps1 positioned dorsally on opisthosomal lobes, closer to bases of $h 3$ than to $h 2$, equidistant from outer and inner margins of lobe. Distance from bases 


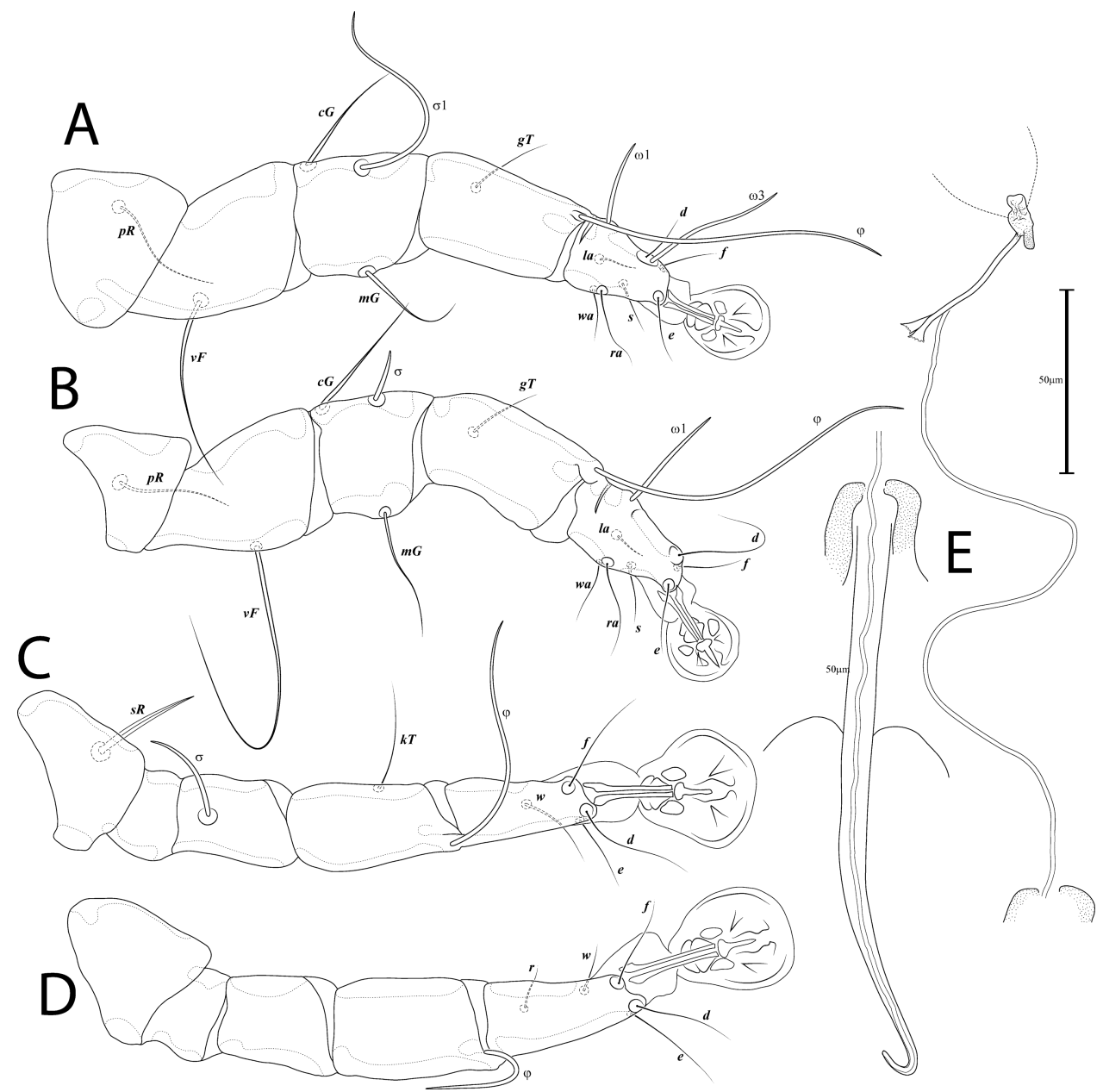

Figure 4. Trouessartia longiducta sp. nov., dorsal view of female legs I (A), II (B), III (C), and IV (D); copulatory tube and spermatheca (E).

of setae $h 3$ to membranous apices of lobes 50-58. Setae $f 2$ present, minute, situated ventrally near bases of setae $h 2$. Supranal concavity open posteriorly into terminal cleft. Length of terminal cleft together with supranal concavity 157-169, width of cleft at level of setae $h 3 \quad 49-52$. Interlobar membrane occupying anterior $1 / 3$ of terminal cleft. External copulatory tube present, cylindrical, attenuate apically, 163-175 long, extending slightly beyond the level of lobar apices (Figures 4E and 5C). Spermatheca as in Figure 4E, secondary spermaducts 37-44 long.

Epimerites I free. Epigynum 54-59 in length, 100-115 in width (Figure 3B). Epimerites IVa present, short. Anal opening with pair of small adanal sclerites situated at level of its anterior end, closer to epimerites IVa than to anal opening. Setae $s R$ of trochanters III narrowly lanceolate, acute apically, 18-31 long. Legs IV extending by ambulacral disc to level of setae psl. Length of solenidia: $\sigma 1$ of genu I $37-65, \sigma$ of genu II $10-16, \sigma$ of genu III $25-32, \varphi$ of tibia I 79-84, $\varphi$ of tibia II 82-92, $\varphi$ of tibia III 55-70, $\varphi$ of tibia IV 20-33, $\omega 1$ of tarsus I 21-26, $\omega 3$ of tarsus I $36-42, \omega 1$ of tarsus II $28-36$.

\section{Differential diagnosis}

Trouessartia longiducta sp. nov. resembles T. geospiza OConnor, Foufopoulos and Lipton, 2005 from ground finches (Emberizidae: Geospiza spp.) in having a long external copulatory tube in females, surpassing the level of insertion of setae $h 3$. Females of the new species are clearly different in having an even longer and wider copulatory tube, slightly surpassing the lobar apices; setae $p s 3$ are shorter and do not reach the bases of ps2; opisthosomal setae $h 1$ are much more robust and dagger-like. In females of T. geospiza, the external copulatory tube does not reach the level of lobar apices; setae $p s 3$ reach the bases of $p s 2$; setae $h 1$ are thin needle-like. In males of T. longiducta sp. nov. the opisthosomal lobes are well separated, the width of terminal cleft is about $1 / 5$ the cleft length, while the width of the terminal cleft in T. geospiza males is about 1/9 the cleft length; the membranous gutter-like extensions are present on tips of genital apparatus parameres (Figure 2E, F) (vs. absent in $T$. geospiza). In both sexes of the new species, the tips of epimerites III are visible as finger-like inner extensions ( $v s$. not extending in T. geospiza). 

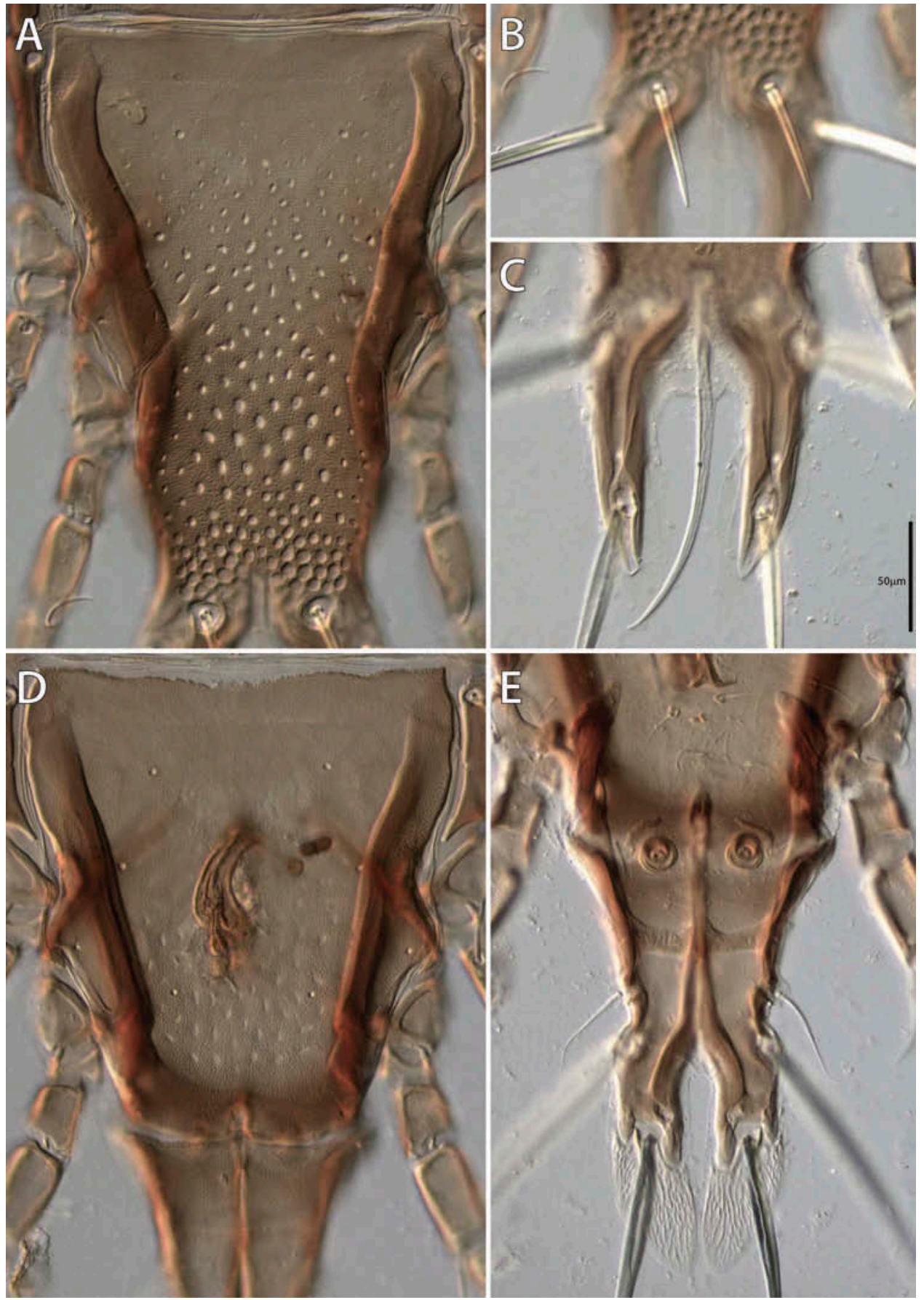

Figure 5. Trouessartia longiducta sp. nov., photomicrographs with differential interference contrast (DIC): dorsal view of female hysteronotal shield (A) and setae $h l$ (B), ventral view of female lobes and copulatory duct (C), dorsal (D) and ventral (E) views of male hysterosoma.

\section{Acknowledgements}

We thank Alexandre M.J. Enout for collecting the mites from Myiobius atricaudus; also the three reviewers of IJA for their invaluable comments and suggestions.

\section{Funding}

This study was supported by FAPESP - São Paulo Research Foundation [to FAH: 2011/50145-0; 2011/20805-8; to MPV: 2011/11420-5; 2012/06951-4].

\section{References}

Berla HF. 1959a. Analgesoidea Neotropicais. II - Três novas espécies de Trouessartia Canestrini, 1899 (Acarina, Proctophyllodidae), hóspedes de Fringillidae (Aves, Passeriformes). Boletim do Museu Nacional, nova série, Zoologia 208:1-8.

Berla HF. 1959b. Analgesoidea Neotropicais. IV - Sôbre algumas espécies novas ou pouco conhecidas de acarinos plumícolas. Boletim do Museu Nacional, nova série, Zoologia 209:1-17. 
Berla HF. 1960. Analgesoidea Neotropicais. VII - Novas espécies de acarinos plumícolas. Anais da Academia Brasileira de Ciências 32:95-105.

Berla HF. 1962. Analgesoidea Neotropicais. IX - Uma nova espécie de Trouessartia Canestrini, 1899. Boletim do Museu Nacional, nova série, Zoologia 241:1-5.

Carleton RE, Proctor HC. 2010. Feather mites associated with Eastern Bluebirds (Sialia sialis L.) in Georgia, including the description of a new species of Trouessartia (Analgoidea: Trouessartiidae). Southeastern Naturalist 9:605-623.

Černý V. 1979. Feather mites (Sarcoptiformes: Analgoidea) of some warblers from Czechoslovakia. Folia Parasitologica 26:81-84.

Černý V, Lukoschus FS. 1975. Parasitic mites of Surinam XXXIII. Feather mites (Analgoidea). Studies on the Fauna of Suriname and other Guyanas 58:184-203.

Constantinescu IC, Chișamera G, Pocora V, Stanciu C, Adam C. 2013. Two new species of feather mites (Acarina: Analgoidea) from the Moustached Warbler, Acrocephalus melanopogon (Passeriformes, Acrocephalidae) in Romania. Zootaxa 3709:267-276.

Dabert J, Mironov SV. 1999. Origin and evolution of feather mites (Astigmata). Experimental \& Applied Acarology 23:437-454.

Dabert M, Witalinski W, Kazmierski A, Olszanowski Z, Dabert J. 2010. Molecular phylogeny of acariform mites (Acari, Arachnida): strong conflict between phylogenetic signal and long-branch attraction artifacts. Molecular Phylogenetics and Evolution 56:222-241.

Dickinson EC. 2003. The Howard and Moore complete checklist of the birds of the world. 3rd ed. Princeton (NJ): Princeton University Press; $1039 \mathrm{pp}$.

Enout AMJ, Lobato DNC, Diniz FC, Antonini Y. 2012. Chewing lice (Insecta, Phthiraptera) and feather mites (Acari, Astigmata) associated with birds of the Cerrado in Central Brazil. Parasitology Research 111:1731-1742.

Gaud J. 1977. La faune terrestre de l'Île de Sainte Hélène. 4.3. Acariens Sarcoptiformes Plumicoles parasites d'oiseaux. Annales du Musée Royale de l'Afrique Centrale, série in$8^{\circ}$, Sciences Zoologiques 220:260-269.

Gaud J, Atyeo WT. 1986. Les Trouessartia (Analgoidea, Trouessartiidae) parasites des hirondelles de l'Ancien Monde. I. Le Groupe appendiculata. Acarologia 27:263-274.

Gaud J, Atyeo WT. 1987. Les Trouessartia (Analgoidea, Trouessartiidae) parasites des hirondelles de l'Ancien Monde. II. Le Groupe minutipes. Acarologia 28:367-379.

Gaud J, Atyeo WT. 1996. Feather mites of the world (Acarina, Astigmata): the supraspecific taxa. Musée Royal de l'Afrique Centrale, Annales, Sciences Zoologiques 277:1-193(Pt. 1, text), 1-436 (Pt. 2, illustrations).

Gaud J, Atyeo WT, Berla HF. 1972. Acariens sarcoptiformes parasites des tinamous. Acarologia 14:393-453.

Hernandes FA. 2014. Five new species of the feather mite genus Trouessartia Canestrini from South America (Acari: Trouessartiidae). Zootaxa 3856:50-72.

Hernandes FA, OConnor BM. 2013. A review of the genus Anisodiscus Gaud \& Mouchet (Acari, Proctophyllodidae) from Madagascar sunbirds (Passeriformes: Nectariniidae), with observations on male genital morphology. International Journal of Acarology 39:423-434.
Kanegae MF, Valim MP, Fonseca MA, Marini MA, Serra-Freire NM. 2008. Ácaros plumícolas (Acari: Astigmata) em aves do Cerrado do Distrito Federal, Brasil. Biota Neotropica 8:30-38.

Krantz GW, Walter DE. 2009. A manual of acarology. 3rd ed. Lubbock (TX): Texas Tech University Press; 807 pp.

Mauri R, De Alzuet AB. 1968. Una nueva espécie de Trouessartia Canestrini, 1899 (Acarina: Proctophyllodidae). Revista del Museo de La Plata, nueva serie, 10, Zoología 85:169-172.

Mestre A, Mesquita-Joanes F, Proctor H, Monrós JS. 2011. Different scales of spatial segregation of two species of feather mites on the wings of a passerine bird. The Journal of Parasitology 97:237-244.

Mironov SV. 1983. Feather mites of the genus Trouessartia of the USSR fauna and descriptions of new species (Analgoidea). Parazitologiya 17:361-369.

Mironov SV, Galloway TD. 2002. New feather mite taxa (Acarina: Analgoidea) and mites collected from native and introduced birds of New Zealand. Acarologia 42:185-201.

Mironov SV, González-Acuña DA. 2013. A new feather mite species of the genus Trouessartia Canestrini, 1899 (Acariformes: Trouessartiidae) from the White-crested Elaenia Elaenia albiceps (D’Orbigny \& Lafresnaye) (Passeriformes: Tyrannidae) in Chile. Acarina 21:123-132.

Mironov SV, Kopij G. 1996. New feather mite species (Acarina: Analgoidea) from some starlings (Passeriformes: Sturnidae) of South Africa. Journal of African Zoology 110:257-269.

Mironov SV, Kopij G. 2000. New feather mites species of the genus Trouessartia (Acari: Analgoidea: Trouessartiidae) from South African passerines (Aves: Passeriformes). Mitteilungen aus dem Hamburgischen Museum und Institut 97:99-115.

Norton RA. 1998. Morphological evidence for the evolutionary origin of Astigmata (Acari: Acariformes). Experimental \& Applied Acarology 22:559-594.

OConnor BM, Foufopoulos J, Lipton D, Lindström K. 2005. Mites associated with the small ground finch, Geospiza fuliginosa (Passeriformes: Emberizidae), from the Galápagos Islands. Journal of Parasitology 91:1304-1313.

Oudemans AC. 1897. List of Dutch Acari, 7 part: acaridiae Latr., 1806, and Phytoptidae Pagenst., 1861, with synonymical remarks in descriptions of new species. Tijdschrift voor Entomologie 40:250-269.

Peterson PC, Atyeo WT, Moss WW. 1980. The feather mite family Eustathiidae (Acarina: Sarcoptiformes). Monographs, Academy of Sciences of Philadelphia 21:1-143.

Santana FJ. 1976. A review of the genus Trouessartia: (Analgoidea: Alloptidae). Journal of Medical Entomology $1: 1-28$.

Valim MP, Hernandes FA. 2010. A systematic review of feather mites of the Pterodectes generic complex (Acari: Proctophyllodidae) with redescriptions of species described by Vladimír Černý. Acarina 18:3-35.

Valim MP, Hernandes FA, Proctor HC. 2011. Feather mites of Brazil (Acari: Astigmata: Analgoidea and Pterolichoidea). International Journal of Acarology 37:293-324.

Walter DE, Proctor HC. 2013. Mites: ecology, evolution \& behaviour - life at a microscale. 2nd ed. New York (NY): Springer; $494 \mathrm{pp}$. 